\title{
The commercially available STAT3 inhibitor 5,15-diphenylporphyrin (5,15-DPP) does not directly interact with STAT3 core residues
} 127-722

\author{
Siphokazi Sinethemba Mtwebana and Earl Prinsloo* ${ }^{*}$
}

\begin{abstract}
Objective: Target specific small molecule inhibitors has driven signaling pathway discovery and are used as common positive controls in drug discovery screens. During a biophysical screen, using surface plasmon resonance spectroscopy, of a novel small molecule library for the Signal Transducer and Activator of Transcription 3 Src Homology 2 (STAT3-SH2) low molecular weight interactors we evaluated commercial inhibitors S3I-201 and 5,15-diphenylporphyrin (5, 15-DPP) as positive controls.

Results: Here, we show using surface plasmon resonance spectroscopy that a common STAT3-SH2 inhibitor, 5,15-diphenylporphyrin (5, 15-DPP), does not bind STAT3 core amino acid residues 127 to 722 relative to another commercially available SH2 inhibitor, S3I-201. This finding should provide caution in data interpretation when using 5,15-DPP in in vitro and in vivo laboratory investigations.
\end{abstract}

Keywords: STAT3, Surface plasmon resonance, JAK-STAT3

\section{Introduction}

It is not uncommon to probe signaling pathways using specific small molecule inhibitors in order to elucidate key cascading events [1]. The deceptively simple Janus kinase-Signal Transducer and Activator of Transcription 3 (JAK-STAT3) signaling pathway has numerous commercially available inhibitors available targeting specific domains of the STAT3 protein [2-4]. The Src Homology 2 ( $\mathrm{SH} 2)$ domain is often targeted as a modulator of a key event in STAT3 activation, namely canonical phosphorylation of tyrosine 705 by Janus kinase 2 and subsequent nuclear targeting. Previously described inhibitors 2-Hydroxy-4-[[[[(4-methylphenyl)sulfonyl] oxy] acetyl] amino]-benzoic acid (NSC 74859) commonly termed

*Correspondence: e.prinsloo@ru.ac.za

Biotechnology Innovation Centre, Rhodes University, P.O. Box 94, Grahamstown 6140, South Africa
S3I-201 and 5,15-diphenylporphyrin (5, 15-DPP) are typically described as SH2 specific inhibitors $[5,6]$.

Discovered through in silico screening, S3I-201 is a cell-permeable STAT3 inhibitor that binds to the STAT3$\mathrm{SH} 2$ domain, prevents phosphorylation/activation, dimerization, and DNA-binding [5]. Similarly, the inhibitor 5,15-DPP has been described as a selective binder to STAT3 as an inhibitor of dimerization by interaction with the Src homology 2 (SH2) domain; reducing nuclear translocation and DNA binding [6].

\section{Main text \\ Methods}

Briefly, surface plasmon resonance (SPR) spectroscopy was performed using the ProteOn ${ }^{\mathrm{TM}} \mathrm{XPR} 36$ Interaction Array System (Bio-Rad) in 40 mM HEPES, pH 7.4, $150 \mathrm{mM} \mathrm{KCl}$ and $5 \mathrm{mM} \mathrm{MgCl}$. The sensor chips were initialized, primed, and preconditioned in horizontal and 
vertical parallel flow channels $0.5 \%(\mathrm{w} / \mathrm{v})$ sodium dodecyl sulfate, $100 \mathrm{mM} \mathrm{HCl}$ and $0.85 \%(\mathrm{v} / \mathrm{v})$ phosphoric acid at $30 \mu \mathrm{L} / \mathrm{min}$. Recombinant mouse STAT3ßtc (core residues 127-722, a kind donation from Dr Christoph W. Müller, EMBL Heidelberg) was expressed, purified [7, 8] and the conformation was assessed using Fourier Transformed Infrared Spectroscopy as previously described by our group [9]; STAT3 was immobilized between 4000 and $6000 \mathrm{RU}$ using standard amine coupling in $20 \mathrm{mM}$ sodium acetate buffer (pH 4$)$ at $30 \mu \mathrm{l} / \mathrm{min}$. Analyte injections of S3I-201 and 5,15-DPP were performed at 30, 60 and $100 \mu \mathrm{L} / \mathrm{min}$ for $60 \mathrm{~s}$ association and $600 \mathrm{~s}$ dissociations to observe interactions and mass transfer effects. Running buffer blank injections were performed following surface pulse regeneration (18 s) using $3 \mathrm{M}$ guanidine $\mathrm{HCl}, 10 \mathrm{mM}$ Tris- $\mathrm{HCl}, \mathrm{pH} 8$ at $100 \mu \mathrm{L} / \mathrm{min}$. All data were collected using the ProteOn Manager (v3.1) and corrected by double referencing using the buffer blank injections and a blank ligand channel.

\section{Results and discussion}

Structural analysis of purified recombinant STAT3 was performed using FTIR spectroscopy (Fig. 1) in the presence and absence of divalent magnesium compared to thermally denatured STAT3. The lack of amide I peak in the thermally denatured samples show that prolonged heating denatures all secondary structures relative to the native secondary structure of the monomer (no metal). As divalent cations have been shown to promote homodimerization of STAT3 [10], FTIR analysis in the the presence of magnesium showed an altered amide I peak relative to the monomeric and denatured samples. Becker et al. [7] describe the homodimerization as a function of the interacting $\mathrm{SH} 2$ domains; the pattern observed in Fig. 1 is likely a result of the interaction.

The sensorgrams shown in Fig. 2a are representative of the effect of increased flow rates $(30-100 \mu \mathrm{L} / \mathrm{min})$ on single concentrations of S3I-201 as analyte with monomeric STAT3 as ligand. The lower flow rates ( 30 and $60 \mu \mathrm{L} / \mathrm{min}$ ) show defined mass transfer limited interactions with the association phase exhibiting linearity whereas the analyte at $100 \mu \mathrm{L} / \mathrm{min}$ shows a clear exponential association phase with the distinct logarithmic decay observable in the dissociation phase without the immediate bulk shift as is displayed by the analyte injections at 30 and $60 \mu \mathrm{L} /$ min, respectively. This served to highlight a defined interaction event between S3I-201 and immobilized STAT3. The small molecule inhibitor 5,15 DPP failed to show any form of interaction (Fig. 2b) where flow rate and increased concentration (Fig. 2c) made little difference to a measurable response in both the association and dissociation phases. Despite the previous report of a high affinity direct interaction by Uehara et al. [6], no data was shown to support the claim of the $K_{D}$ of $880 \mathrm{nM}$.

\section{Limitations}

One caveat to the work shown here may be that 5,15 DPP may indeed bind STAT3 but not at the SH2 domain; the construct used lacks the first 126 amino acids of the $\mathrm{N}$-terminal cooperative DNA binding domain required for STAT3 concatemerization at DNA binding sites and may play a role in transcriptional regulation [11]. Taken together with the data presented by Uehara et al. [6] i.e. that tyrosine phosphorylation is not inhibited and

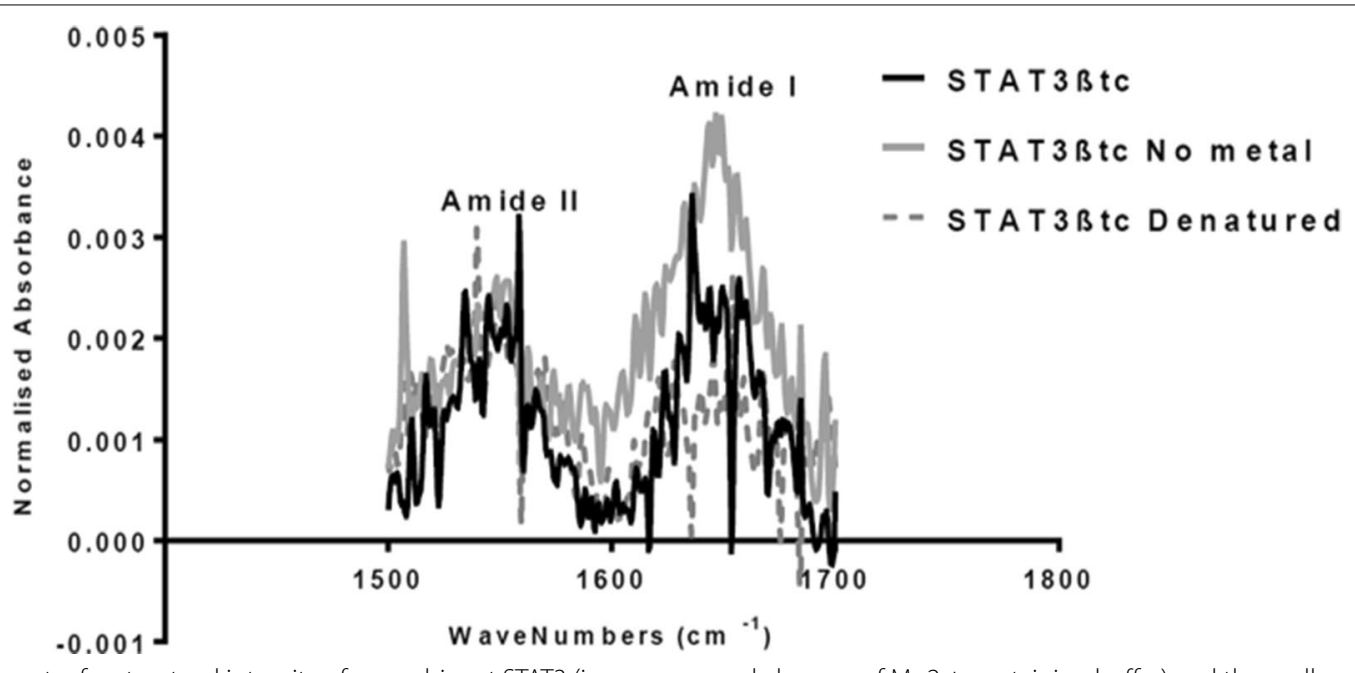

Fig. 1 FTIR spectra for structural integrity of recombinant STAT3 (in presence and absence of Mg2 + containing buffer) and thermally denatured protein. Spectra represent Amide II (1500-1600 cm $\mathrm{cm}^{-1}$ ) and Amide I $\left(1600-1700 \mathrm{~cm}^{-1}\right)$. Divalent cations have been shown to promote homodimerization of STAT3 [10], this appears to have resulted in an altered Amide I peak 

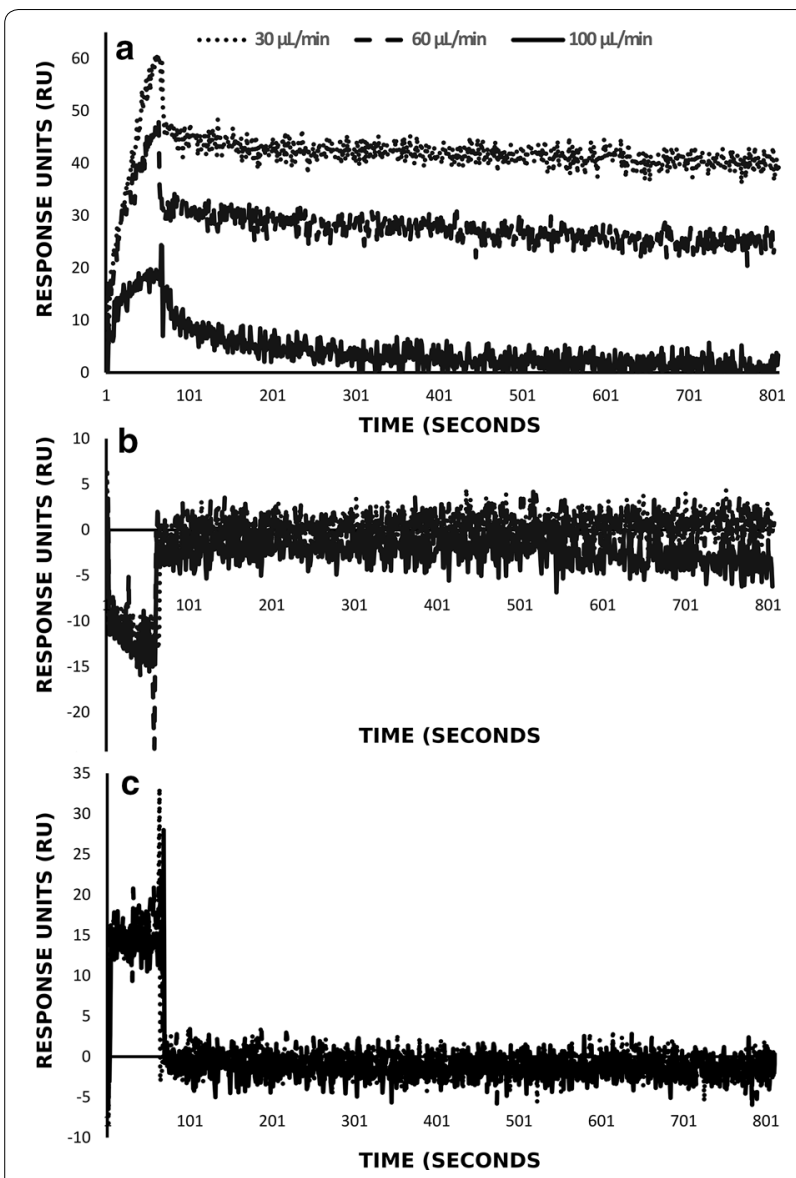

Fig. 2 Sensorgrams showing comparative binding of immobilized recombinant STAT3 to commercial inhibitors (a) S3I-201 at $80 \mu \mathrm{M}$ (b) 5, 15-DPP at $80 \mu \mathrm{M}$ and (c) 5,15-DPP at $100 \mu \mathrm{M}$. Sensorgrams are representative of 3 flow rates as indicated

a decrease in nuclear localization and DNA binding is observed it may in fact be that 5,15-DPP interacts with regions in the $\mathrm{N}$ terminal of STAT3. Although it cannot be discounted that the observations of STAT3 inhibition by 5,15-DPP may be as a result of a positive off target effect. We do believe however, based on the data presented here taken together with the work of Uehara et al. [6], that 5,15-DPP should not be marketed as an SH2 inhibitor.

\section{Supplementary information}

Supplementary information accompanies this paper at https://doi. org/10.1186/s13104-020-05189-w.

Additional file 1. Representative exported dataset of controls S3I-201 and 5,15-DPP from surface plasmon resonance spectroscopy screening experiment used to generate Fig. 2. Data for single concentration ( $80 \mu \mathrm{M})$ included are values collected at 30,60 and $100 \mu \mathrm{L} / \mathrm{min}$. Data for single concentration $(100 \mu \mathrm{M})$ of 5, 15-DPP included at same flow rates.

\section{Abbreviations}

STAT3: Signal transducer and activator of transcription 3; STAT3ßtc: Signal transducer and activator of transcription 3 beta truncated; $\mathrm{SH} 2: \mathrm{Src} 2 \mathrm{Homol}-$ ogy; JAK: Janus kinase; 5, 15-DPP: 5,15-diphenylporphyrin; SPR: Surface plasmon resonance spectroscopy; RU: Response units.

\section{Acknowledgements}

We would like to thank Rhodes University, the South African Department of Science \& Technology and National Research Foundation for funding and infrastructure.

\section{Authors' contributions}

SSM and EP conceived the experiment. SSM collected data and performed experiments. SSM and EP analyzed the data and wrote the manuscript. Both authors read and approved the final manuscript.

\section{Funding}

Department of Science and Technology (DST), National Research Foundation (NRF) and Rhodes University for funding. The Biorad ProteOn XPR36 Interaction Array System was purchased under the NRF/DST National Nanotechnology Equipment Program. SSM is a recipient of a DST/NRF Scarce Skills Masters scholarship.

\section{Availability of data and materials}

Raw data for the SPR data is provided as Additional file 1. The FTIR data is provided as processed data in the article.

\section{Ethics approval and consent to participate}

Not applicable.

\section{Consent for publication}

Not applicable.

\section{Competing interests}

The authors declare that they have no competing interests.

Received: 19 May 2020 Accepted: 16 July 2020

Published online: 20 July 2020

\section{References}

1. Castoreno AB, Eggert US. Small molecule probes of cellular pathways and networks. ACS Chem Biol. 2011;6:86-94. https://doi.org/10.1021/cb100 2976.

2. Furtek SL, Backos DS, Matheson CJ, Reigan P. Strategies and approaches of targeting STAT3 for cancer treatment. ACS Chem Biol. 2016;11(2):30818. https://doi.org/10.1021/acschembio.5b00945.

3. Yue P, Turkson J. Targeting STAT3 in cancer: how successful are we? Expert Opin Investig Drugs. 2009;18:45-56. https://doi.org/10.1517/1354378080 2565791.

4. Fagard R, Metelev V, Souissi I, Baran-Marszak F. STAT3 inhibitors for cancer therapy: have all roads been explored? JAK-STAT. 2013;2:e22882. https:// doi.org/10.4161/jkst.22882.

5. Siddiquee K, Zhang S, Guida WC, Blaskovich MA, Greedy B, Lawrence $H R$, et al. Selective chemical probe inhibitor of Stat3, identified through structure-based virtual screening, induces antitumor activity. Proc Natl Acad Sci. 2007;104:7391-6. https://doi.org/10.1073/PNAS.0609757104.

6. Uehara Y, Mochizuki M, Matsuno K, Haino T, Asai A. Novel high-throughput screening system for identifying STAT3-SH2 antagonists. Biochem Biophys Res Commun. 2009;380:627-31. https://doi.org/10.1016/j. bbrc.2009.01.137.

7. Becker S, Groner B, Müller CW. Three-dimensional structure of the Stat3beta homodimer bound to DNA. Nature. 1998;394:145-51. https://doi. org/10.1038/28101.

8. Becker S, Corthals GL, Aebersold R, Groner B, Müller CW. Expression of a tyrosine phosphorylated, DNA binding Stat $3 \beta$ dimer in bacteria. FEBS Lett. 1998;441:141-7. https://doi.org/10.1016/50014-5793(98)01543-9.

9. Prinsloo E, Kramer A, Edkins A, Blatch G. STAT3 interacts directly with Hsp90. IUBMB Life. 2012;64:266-73. 
10. Novak U, Ji H, Kanagasundaram V, Simpson R, Paradiso L. STAT3 forms stable homodimers in the presence of divalent cations prior to activation. Biochem Biophys Res Commun. 1998;247:558-63. https://doi. org/10.1006/bbrc.1998.8829.

11. Hu T, Yeh JE, Pinello L, Jacob J, Chakravarthy S, Yuan G-C, et al. Impact of the N-terminal domain of STAT3 in STAT3-dependent transcriptional activity. Mol Cell Biol. 2015;35:3284-300. https://doi.org/10.1128/ mcb.00060-15.

\section{Publisher's Note}

Springer Nature remains neutral with regard to jurisdictional claims in published maps and institutional affiliations.
Ready to submit your research? Choose BMC and benefit from:

- fast, convenient online submission

- thorough peer review by experienced researchers in your field

- rapid publication on acceptance

- support for research data, including large and complex data types

- gold Open Access which fosters wider collaboration and increased citations

- maximum visibility for your research: over 100M website views per year

At BMC, research is always in progress.

Learn more biomedcentral.com/submissions 